American J. of Engineering and Applied Sciences 4 (4): 497-503, 2011

ISSN 1941-7020

(C) 2014 B.B.M. Dewu et al., This open access article is distributed under a Creative Commons Attribution

(CC-BY) 3.0 license

\title{
Evaluation and Beneficiation of Bentonitic Clays from Pindiga Formation in Benue Trough
}

\author{
${ }^{1}$ Dewu, B.B.M., ${ }^{1}$ I.I. Funtua, ${ }^{1}$ M.O.A. Oladipo, ${ }^{1}$ S.A. Arabi, \\ ${ }^{2}$ I.A. Mohammed-Dabo, ${ }^{1}$ A.M. Muhammad and ${ }^{3}$ I. Hamidu \\ ${ }^{1}$ Center for Energy Research and Training, Ahmadu Bello University, Zaria-Nigeria \\ ${ }^{2}$ Department of Chemical Engineering, Faculty of Engineering, Zaria-Nigeria \\ ${ }^{3}$ Department of Geology, Faculty of Science, Zaria-Nigeria
}

\begin{abstract}
Problem statement: This study aimed at evaluating and beneficiating Bentonitic clays of Pindiga Formation from the upper Benue trough in northeastern Nigeria to meet the standard required for use in oil well drilling. This will reduce the dependence on imported Bentonite into the country, increase foreign exchange, improve the country's economy and create employment opportunities. Approach: Three clay samples from different locations within Pindiga Formation were collected using standard sampling procedure and brought to the laboratory for the study. Evaluation of Loss On Ignition (LOI) was carried out using "Labocon" Furnace (model 2-1200), elemental composition of the samples were determined using Instrumental Neutron Activation Analysis (INAA) and X-Ray Fluorescence (XRF) while mineralogical phases of the samples were determined by X-Ray Diffractometry. Results: Results of analysis of crude Bentonitic clays indicates that the clays are Ca-based which require some level of beneficiation before they can attain the properties that will qualify its use in oil well drilling, while other properties such as Aluminum-Silicon ration which ranges between $0.34-0.39$ as against 0.38 for the standard Wyoming Bentonite, LOI ranges between 14.8-15.63 as against 15.73 for the standard and fineness of the samples all attained the required standard even before beneficiation. After beneficiating the samples, their rheological and other physical properties was found to have improved to a level that is acceptable for use in oil well drilling except for yield points which was still lower. Maximum values recorded for viscosity and yield points for crude and beneficiated samples at 300 and $600 \mathrm{rpm}$ are 5, 34.5 and 3, 9 while 15 was recorded for floating drill cuttings, respectively. API has specified the viscosity and yield to be $\geq 30$ for viscosity at $600 \mathrm{rpm}$ and yield point at $\leq 3$. Conclusion: This result indicates that Bentonitic clays from Pindiga Formation in Benue trough, northeastern Nigeria are Ca-base but can be beneficiated using sodium carbonate as beneficiating agent and ion exchange procedure.
\end{abstract}

Key words: X-Ray Diffraction (XRD), Instrumental Neutron Activation Analysis (INAA), Loss On Ignition (LOI), floating drill cuttings, Technology Development Fund (PTDF)

\section{INTRODUCTION}

Bentonite is a clay that is used in wellbore drilling operations primarily to float drill cuttings out of the hole by continually circulating it from the mud pit through the drill string down the hole and out through the annular space surrounding the string. Apart from floating drill cuttings, it also cools, lubricate the bit and hold cuttings in suspension at some points during drilling operations. The cleaning performance of bentonite is affected by many factors such as fluid viscosity, annular flow velocity, angle of inclination and drill cuttings size and shape (Al-Kayiem et al., 2010). Abdessemed and Nezzal (2008), determined the userbility of Bentonite used as adsorbent agent of the coupling adsorption ultra filtration of the secondary affluent for their Reuse. There is no single oil well that was drilled without the use of Bentonite; therefore its importance in drilling operations in oil and gas well construction cannot be overemphasized. The use of Bentonite in drilling operations in the oil and gas industry in the country is very significant; therefore any effort that is geared toward reducing the overdependence on imported Bentonite by the oil companies will go a long way in reducing the large sum of money spent on importation of foreign reserve thereby boosting the country's economy and create employment opportunity. This group of clay has been

Corresponding Author: S.A. Arabi, Center for Energy Research and Training, Ahmadu Bello University, Zaria-Nigeria 
studied by Falode et al. (2008) from same Pindiga formation, his beneficiation procedures adopted the use of $\mathrm{Na}_{2} \mathrm{CO}_{3}$,potash and starch. He concluded his remark that beneficiated Pindiga clay gives a good promise for drilling purposes at optimum clay and additives concentration. This study has evaluated and improved the quality of local Bentonite occurrences from Pindiga Formation in Benue trough, north-eastern Nigeria by ion exchange to meet standards required for application as a drilling mud in the oil and gas industry.

Pindiga Formation is a marine deposit within the Benue trough (Fig. 1) consisting of five members namely; the Kanawa, Deba Fulani, Gulani, Dumbulwa and Fika Member.

The Gulani, Deba Fulani and Dumbulwa Members are lateral lithofacies equivalents occurring in the middle part of the Pindiga Formation. The Kanawa Member provides an excellent stratigraphical marker horizon between the sandy units above and below. It produces a low featureless topography and weathers to a distinctive black, cotton soil which is heavily cultivated. The Gulani Member contains relatively thinly bedded $(5-6 \mathrm{~cm})$ coarse and very coarse-grained pebbly sandstones with purple, brown and white laminated mudstone interbeding each less than $1 \mathrm{~m}$ thick, but very thick cross-bedded sandstones are most characteristic (Zaborski et al., 1997). The Deba Fulani Member contains relatively coarse-grained pebbly tabular cross-bedded sandstones, fining upwards channel-filling sandstones, thinly bedded sandstones. The Dumbulwa Member is largely made up of finingupwards fluvial cycles, when complete each about $10 \mathrm{~m}$ thick. Localized developments of persistent tabular cross-bedded sandstone also occur (Zaborski, 1998).

The Fika Member comprises the "Fika Shales" and produces a low featureless topography. Its outcrop can often be recognized from the black, shrinking clay soil to which it gives rise (Zaborski et al., 1997). The exposures that do occur mostly reveal shaly mudstones, dark grey when fresh but weathering to lighter bluegreen to grey colors indistinguishable from those of Kanawa Member. They lack macrofossils and contain irregular bands and lenses of gypsum.

Three representative samples from different locations namely; Pindiga, Futuk and Arawa River Channel (Fig. 1) within Pindiga Formation were collected and subjected to samples preparation and beneficiation procedures and a total of thirty three samples were generated each with different percentage of the beneficiating agent added. The samples generated were subjected to analysis and determinations of elemental, rheological and other physical properties.

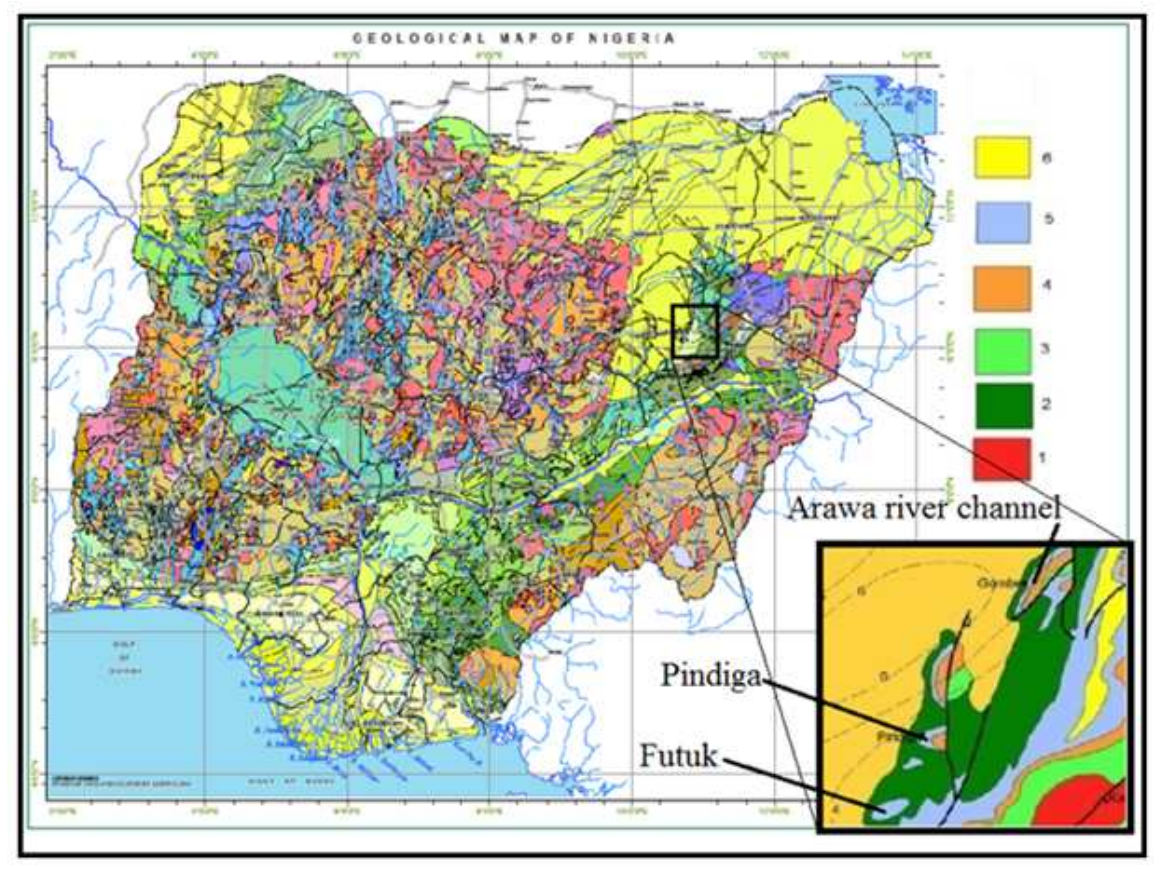

Fig. 1: Geological map of Nigeria showing location of the study area and the points sampled (1) Precambrian; (2) Gombe sandstone; (3) Bima group; (4) Yolde formation; (5) Pindiga Formation; (6) Sandy members of the Pindiga Formation in the Gongola Basin; (NFS, 1956 and based on Benkhelil, 1985; Guiraud, 1989; Zaborski et al., 1997) 
Am. J. Engg. \& Applied Sci., 4 (4): 497-503, 2011

These parameters were found to compare well with the Wyoming Bentonite and the API standard.

\section{MATERIALS AND METHODS}

The clay samples were collected in April, 2009, mostly along river channel where they were cut across by deep gullies created by streams and river in the areas sampled. Surface of an exposed sample was carefully removed using plastic shovels and the samples were collected and packed into plastic container and each samples container was properly labeled to reflect location name, date and time of collection. These were also recorded into a samples details book together with coordinates of the sampled points.

Samples brought from site were subjected to different experimental works with the aim to determine the elemental, rheological and other physical properties of raw sample in order to prepare the most suitable activity that will be carried out on them. Initial elemental analysis were carried out to determine either a sample will require no, little or intense beneficiation. For example, if a sample is discovered to be a Nabased, rheological property determination will proceed immediately to determine whether their property has met that of a standard. If a sample is discovered otherwise, elemental analysis is carried out to determine the extent of addition of beneficiating agent for ion exchange procedure.

Analysis of raw Bentonitic clays were carried out using Instrumental Neutron Activation Analysis (INAA), X-Ray Fluorescence (XRF) and X-Ray Diffractometry (XRD) to determine the elemental composition, especially the $\mathrm{Ca}$ and $\mathrm{Na}$ content and rheological properties before beneficiation was carried out.

Sample preparations include the following.

Addition of beneficiating agent: From each of the sample, nine sets of ten $100 \mathrm{~g}$ of each sample were set aside for addition of the beneficiating $\left(\mathrm{Na}_{2} \mathrm{CO}_{3}\right)$ as shown in Table 1.

From this process, a total of 33 samples were generated and further steps of the beneficiation procedure were followed.

Kneading of samples: To each of the samples (sample with sodium carbonate), $50 \mathrm{~mL}$ of deionized distilled water was added and kneaded into a dough like mass and allow to stay overnight for ion exchange to take place.

Drying of kneaded samples: After allowing the kneaded samples to stay overnight for ion exchange to occur, each of the samples were oven dried at $75^{\circ}$ for eight $h$.

\begin{tabular}{lll}
\multicolumn{2}{l}{ Table 1: Quantity of sample and beneficiating agent added } \\
\hline $\begin{array}{l}\text { Quantity of } \\
\text { samples }(\mathrm{g})\end{array}$ & $\begin{array}{l}\text { Quantity of } \\
\mathrm{Na}_{2} \mathrm{CO}_{3}(\mathrm{~g})\end{array}$ & $\begin{array}{l}\text { Total weight } \\
\text { of sample }(\mathrm{g})\end{array}$ \\
\hline 100 & 2 & 102 \\
100 & 3 & 103 \\
100 & 4 & 104 \\
100 & 5 & 105 \\
100 & 6 & 106 \\
100 & 7 & 107 \\
100 & 8 & 108 \\
100 & 9 & 109 \\
100 & 10 & 110 \\
100 & 11 & 111 \\
\hline
\end{tabular}

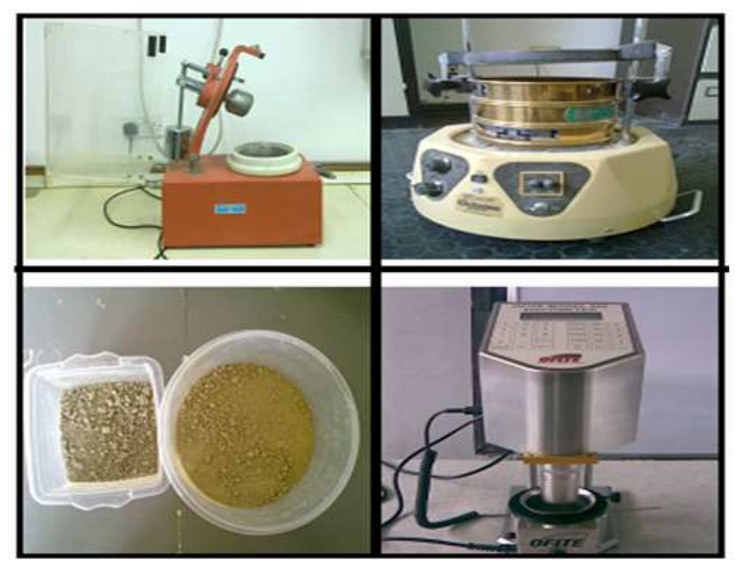

Fig. 2: Some of the equipment used in this study, top left: Grinding machine, top right: Sieve Shaker, bottom left: Crushed Bentonitic clay sample and bottom right: Viscometer

Re-grinding and sieving of beneficiated samples: The beneficiated samples were re-grinded sieved again to achieve the $63 \mu$. A direct indicating OFITE MODEL 900 VISCOMETER (Fig. 2) was used to determine the viscosity of the samples, Moisture Content and Loss On Ignition were determined at 110 and $1000^{\circ} \mathrm{C}$ after 30 and 45min, respectively using "Labcon" Furnace Model 2-1200 while Sand content was determined by Bariod sand kit equipped with a set of sand screen.

\section{RESULTS}

Chemical compositions of the samples were determined and results were compared with that of a standard Wyoming Betonies. Loss on ignition and moisture content were also determined and these results are given in Table 2 and 3.

$\mathrm{X}$ Ray Diffraction (XRD) was carried out to determine the mineralogical phases of the samples. The result obtained is presented in Table 4. 
Am. J. Engg. \& Applied Sci., 4 (4): 497-503, 2011

Table 2: Elements determined in the samples compared with the Wyoming Bentonite

\begin{tabular}{|c|c|c|c|c|}
\hline Composition & $\begin{array}{l}\text { Arawa river } \\
\text { channel }\end{array}$ & $\begin{array}{l}\text { Pindiga } \\
\text { town }\end{array}$ & $\begin{array}{l}\text { Futuk } \\
\text { town }\end{array}$ & Wyoming \\
\hline $\mathrm{SiO}_{2}$ & 52.80 & 53.00 & 46.76 & 47.37 \\
\hline $\mathrm{Al}_{2} \mathrm{O}_{3}$ & 20.80 & 18.00 & 18.40 & 17.82 \\
\hline $\mathrm{Fe}_{2} \mathrm{O}_{3}$ & 7.53 & 4.68 & 8.17 & 1.72 \\
\hline $\mathrm{MgO}$ & 2.95 & 2.60 & 2.34 & 1.50 \\
\hline $\mathrm{CaO}$ & 0.77 & 0.67 & 0.57 & 1.41 \\
\hline $\mathrm{K}_{2} \mathrm{O}$ & 2.61 & 2.28 & 2.59 & 0.88 \\
\hline $\mathrm{Na}_{2} \mathrm{O}$ & 0.28 & 0.61 & 0.45 & 15.41 \\
\hline $\mathrm{TiO}_{2}$ & 0.67 & 0.90 & 0.70 & 41.70 \\
\hline $\mathrm{Al}_{2} \mathrm{O}_{3} / \mathrm{SiO}_{2}$ & 0.39 & 0.34 & 0.39 & 0.38 \\
\hline
\end{tabular}

Table 3: Results of loss on ignition and moisture contents of the studied samples

\begin{tabular}{|c|c|c|c|c|}
\hline \multirow[b]{2}{*}{$\begin{array}{l}\text { Geologic formation } \\
\text { Sample ID }\end{array}$} & \multicolumn{3}{|c|}{ Pindiga formation } & \multirow[b]{2}{*}{$\begin{array}{l}\text { Standard } \\
\text { Wyoming }\end{array}$} \\
\hline & $\begin{array}{l}\text { Arawa river } \\
\text { channel }\end{array}$ & $\begin{array}{l}\text { Pindiga } \\
\text { town }\end{array}$ & $\begin{array}{l}\text { Futuk } \\
\text { town }\end{array}$ & \\
\hline Moiture content at $110^{\circ} \mathrm{C}$ & 0.03 & 0.03 & 0.03 & 0.03 \\
\hline losson ignition & 0.08 & 0.08 & 0.07 & 0.08 \\
\hline Loss on ignition (\%) & 15.63 & 15.12 & 14.82 & 15.73 \\
\hline
\end{tabular}

Table 4: Mineralogical phases of the studied samples (phase percentage may differ in all the samples)

\begin{tabular}{ll}
\hline Sample ID & Mineral phases \\
\hline Arawa River channel & Montmorillonite, Kaolinite, Dolomite, \\
& Illite, Quartz and Microcline \\
Pindiga town & Montmorillonite, Kaolinite, Dolomite, \\
& Illite, Quartz and Microcline \\
Futuk town & Montmorillonite, Kaolinite, Dolomite, \\
& Illite, Quartz and Microcline \\
Wyoming & Montmorillonite, Calcite, Dolomite, Barite, \\
& Quartz, Microcline, Beidellite and Ankerite \\
\hline
\end{tabular}

Rheological properties such viscosity at 300$600 \mathrm{rpm}$ and yield point were measure in three fold for each sample, these are for crude samples, sieved beneficiated samples and sieved beneficiated with viscosifier added. The results of these are given in figures to for samples from Futuk and Pindiga Towns, respectively.

\section{DISCUSSION}

The results of chemical composition of some elements that were determined using Instrumental Neutron Activation Analysis (INAA) and X Ray Fluorescence (XRF) were compared with Wyoming Bentonite (standard) and presented in Table 2. This results showed that the oxides of $\mathrm{Si}, \mathrm{Al}, \mathrm{Fe}, \mathrm{Mg}, \mathrm{Ca}, \mathrm{K}$ and Na ranges from 46.8-53, 18-20.8, 4.7 - 8.2, 2.3-3.0, $0.57-0.77,2.28-2.6$ and $0.28-0.61 \%$, respectively. Analysis of wyoming bentonite showed these results to be $47.4,17.8,1.7,1.5,1.41,0.58$ and $15.4 \%$, respectively. These results confirmed that the Wyoming Bentonite is Na-based while the studied clays are Ca- based because the range of $\mathrm{Ca}$ to $\mathrm{Na}$ in the studied samples is $0.57-0.77 \%$ while it is $1.41-15.4 \%$ in wyoming bentonite. For the studied samples, the $\mathrm{Al} / \mathrm{Si}$ (aluminum-silica ratio) ranges from $0.34-0.39$ while it is 0.38 in wyoming bentonite indicating that the $\mathrm{Al} / \mathrm{Si}$ of the studied sample has met the standard even before beneficiation. The moisture content as determined for both studied samples and the wyoming bentonite is $0.3 \%$ and the API recommendation is $\leq 13$ indicating that moisture content of both studied samples and the wyoming bentonite complied with the API standard. Loss on ignition for studied samples ranges from 14.815.63 and $15.73 \%$ for the standard. This also showed that percentage loss on ignition for both samples and standard were within same range (Table 3). In an article titled "Determination of trace elements by INNA in Anatolian Bentonitic clays" Gungor et al. (1998) reported that Cabased bentonitic clays are representative of of primary deposition environment and the relatively high amount of REE found in them brings about porosity problems in the use of Ca-bentonite in cement and concrete production.

The result of X Ray Diffractometry is given in Table 4. These results showed that both studied sample and the Wyoming Bentonite had Silica, Dolomite, Microcline and montmorillonite, while Barite appeared only in the wyoming bentonite, indicating that wyoming bentonite has been blended with Barite to improve some of its rheological and physical properties. The average residue of the studied samples is 3 which also met the $\leq 4$ at $75 \mu \mathrm{m}$ of the API standard.

The viscosity of crude beneficiated (not sieved) samples at 300 and $600 \mathrm{rpm}$ for Futuk and Pindiga ranged from 1.2-3, 2.1-3 and 2.1-4.5, 3.5-5 with maximum at 9, 5 and 3, $4 \% \mathrm{Na}_{2} \mathrm{CO}_{3}$, respectively (Fig. 3-5). These indicate that at 300 and $600 \mathrm{rpm}$, the viscosities of crude sample do not meet the API standard.

For samples that were sieved before beneficiated (sieved beneficiated), the viscosities improved a little above that recorded in crude beneficiated sample; the viscosity at $300 \mathrm{rpm}$ for Futuk sieved beneficiated samples ranges from 2.5-5 against 2.2-3 for crude samples while it is 2.5-6.5 in Pindiga against 2.1-3 recorded for crude samples with maximum viscosities at 8 and $9 \% \mathrm{Na}_{2} \mathrm{CO}_{3}$. At $600 \mathrm{rpm}$, the viscosities are 57.5 and 4-9 for Futuk and Pindiga against 2.1-4.5, 3.5-5 for crude beneficiated, with maximum at $10 \% \mathrm{Na}_{2} \mathrm{CO}_{3}$ for both Futuk and Pindiga, respectively.

In wyoming bentonite, the recorded viscosities at 300 and $600 \mathrm{rpm}$ were 15 and 22, respectively (Fig. 6 and 7). This shows that the viscosities of the sieved beneficiated samples did not meet the API standard nor that of Wyoming Bentonite. 
Am. J. Engg. \& Applied Sci., 4 (4): 497-503, 2011
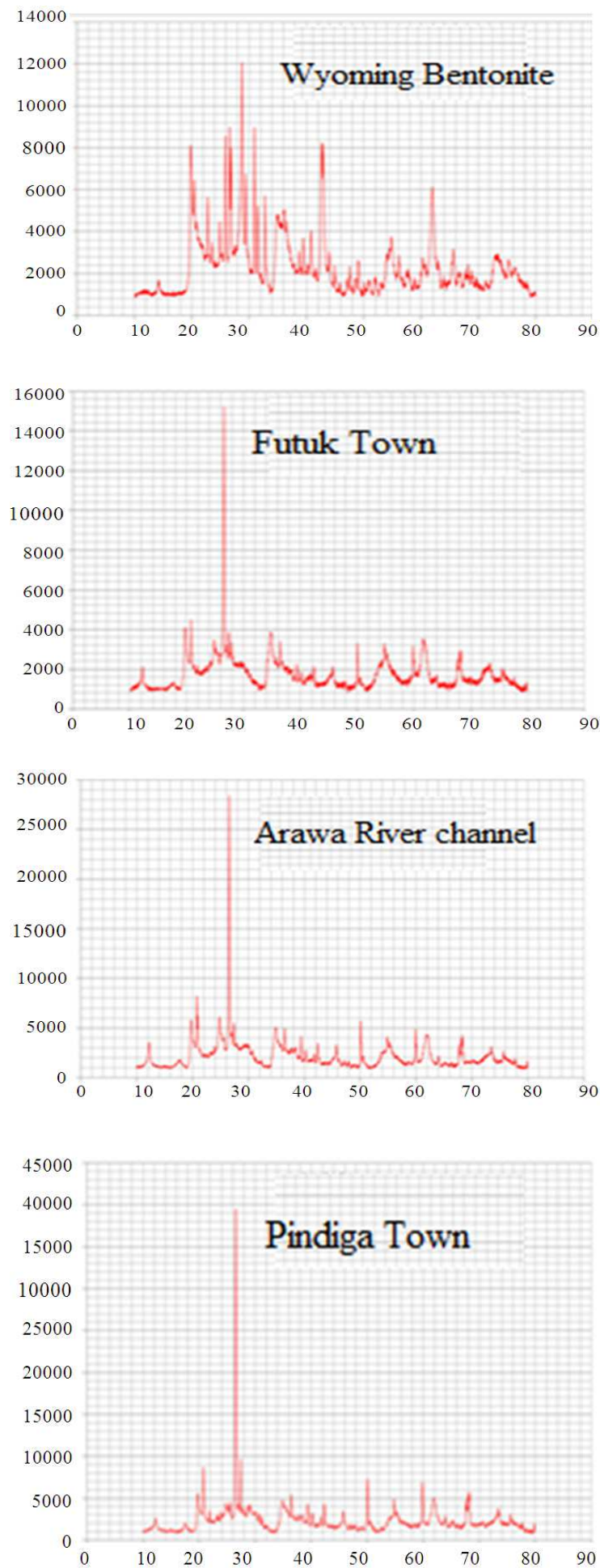

Fig. 3: XRD spectra for wyoming bentonite, futuk, arawa river channel and pindiga town

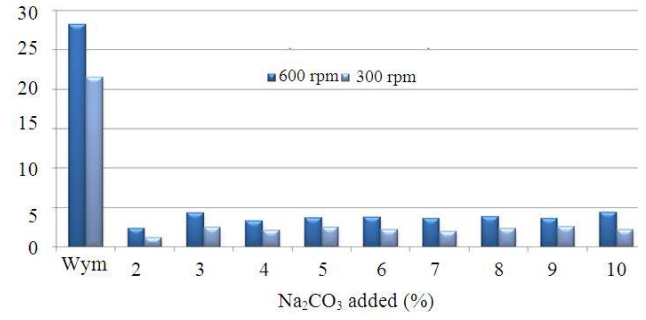

Fig. 4: Comparison of Viscosity of Wyoming Bentonite and crude sample from Futuk town at 300 and $600 \mathrm{rpm}$

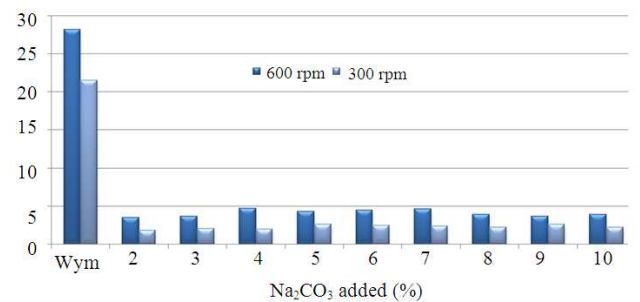

Fig. 5: Comparison of Viscosity of Wyoming Bentonite and crude sample from Pindiga town at 300 and $600 \mathrm{rpm}$

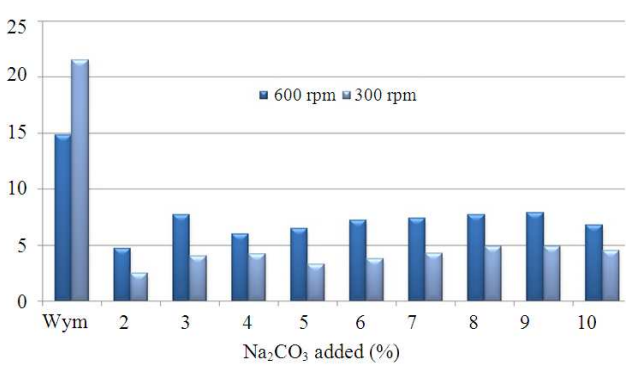

Fig. 6: Comparison of Viscosity of Wyoming Bentonite and sieved beneficiated sample from Futuk town at 300 and $600 \mathrm{rpm}$

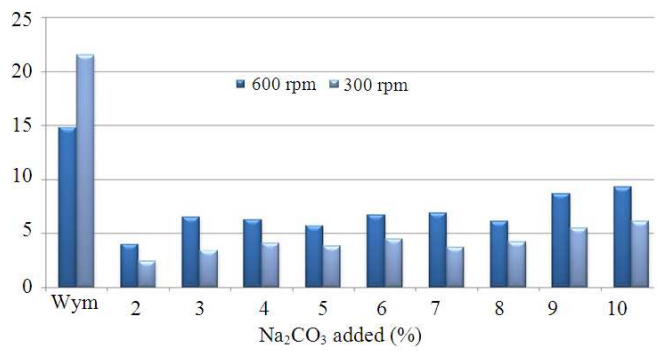

Fig. 7: Comparison of Viscosity of Wyoming Bentonite and sieved beneficiated sample from Pindiga town at 300 and $600 \mathrm{rpm}$ 
Am. J. Engg. \& Applied Sci., 4 (4): 497-503, 2011

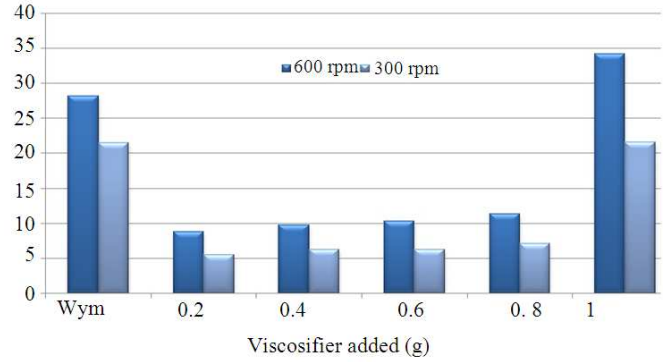

Fig. 8: Comparison of Viscosity of Wyoming Bentonite and sieved beneficiated sample from Futuk town at 300 and $600 \mathrm{rpm}$ after viscosifier

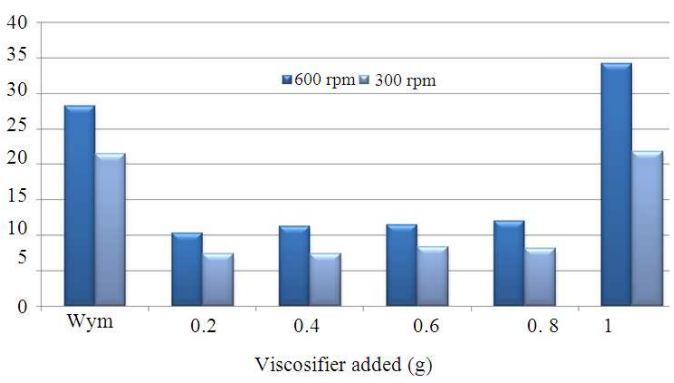

Fig. 9: Comparison of Viscosity of Wyoming Bentonite and sieved beneficiated sample from Pindiga town at 300 and $600 \mathrm{rpm}$ after viscosifier was added

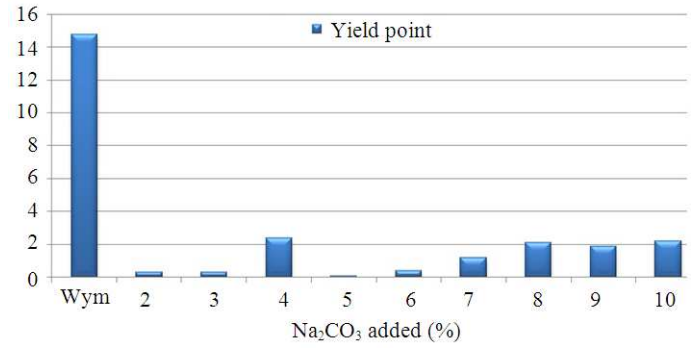

Fig. 10: Comparison of Yield point of Wyoming Bentonite and sieved beneficiated sample from Futuk town

After a viscosifier was added to the sieved beneficiated samples, the viscosity improved dramatically. The viscosities recorded for sieved beneficiated samples at 300rpm when viscosifier was added in the range of $0.1-1 \mathrm{~g}$ is $5.7-21$ and 7-22 with maximum viscosity at $1 \mathrm{~g}$ viscosifier for both Futuk and Pindiga, respectively. While at 600rpm the viscosities were 9-34 and 10.2-34.5 with maximum viscosities at $1 \mathrm{~g}$ viscosifier for Futuk and Pindiga, respectively. These values are against 22 and 28 at 300 and $600 \mathrm{rpm}$ for wyoming bentonite, respectively (Fig. 8 and 9).

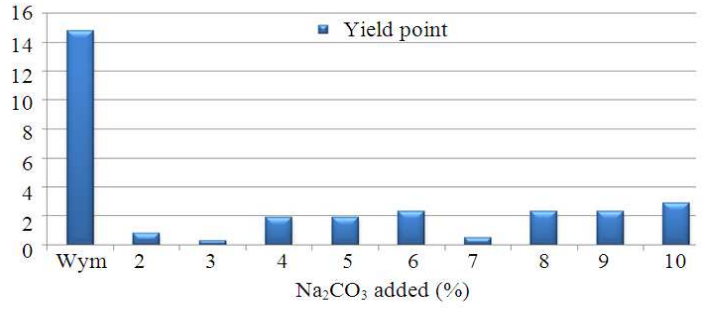

Fig. 11: Comparison of Yield point of Wyoming Bentonite and sieved beneficiated sample from Pindiga town

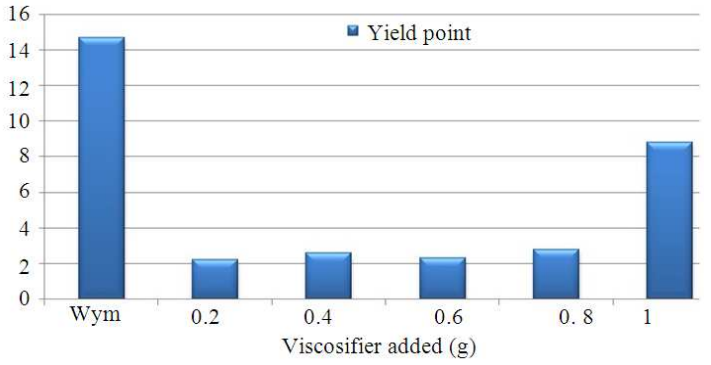

Fig. 12: Comparison of Yield point of Wyoming Bentonite and sieved beneficiated sample from Futuk town after viscosifier was added

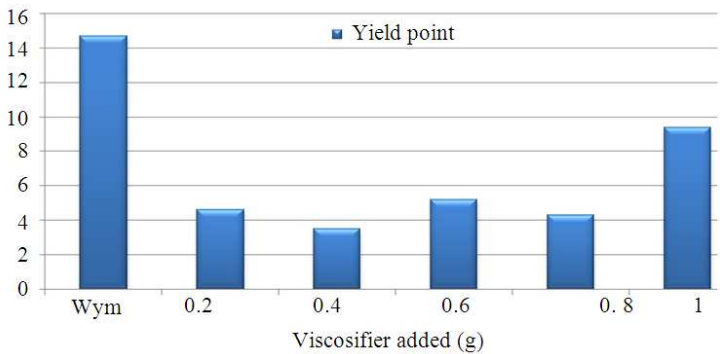

Fig. 13: Comparison of Yield point of Wyoming Bentonite and sieved beneficiated sample from Pindiga town after viscosifier was added

This means that with the addition of viscosifier, the viscosities of the studied samples have met the API standard of $\geq 30$ at $600 \mathrm{rpm}$.

The yield points recommended by the API standard $\leq 3$, for the studied samples, the yield points recorded are 0.1-2.5 for Futuk with maximum at 4\% $\mathrm{Na}_{2} \mathrm{CO}_{3}$ and $0.2-3$ for Pindiga with maximum yield at $10 \% \mathrm{Na}_{2} \mathrm{CO}_{3}$. These yield values recorded fall within the API recommended value while for Wyoming Bentonite, the yield recorded was 15 which fall outside the $\leq 3$ recommended by API (Fig. 10 and 11). When viscosifier was added to the 
samples, the yield points exceeded the API value at $1 \mathrm{~g}$ viscosifier for Futuk, but complied well with the API value at $0.8 \mathrm{~g}$ Viscosifier and the complied value for Pindiga was at $0.4 \mathrm{~g}$ viscosifier (Fig. 12 and 13) while for Wyoming, it remains at 15 . The yield point recorded for Futuk ranged from 2-9 with maximum of 9 at $1 \mathrm{~g}$ viscosifier and 3.5-9 for Pindiga also at $1 \mathrm{~g}$ viscosifier. This implies that whereas the studied samples had yield values that fall within the API specified value, the Wyoming Bentonite did not comply with yield point value as recommended by the API.

\section{CONCLUSION}

The Results of INAA and XRF of the samples studied showed that they are Ca-based whereas the Wyoming Bentonite is Na-based. After beneficiating the samples using $\mathrm{Na}_{2} \mathrm{CO}_{3}$ as the beneficiating agent, the $\mathrm{Na}$ contents of the samples improved considerably indicating that the ion exchange procedure adopted really improved not only the $\mathrm{Na}$ content of the samples but has enter the bond that enhances rheological properties of clays. Other parameters such as loss on ignition, moisture content and $\mathrm{Al} / \mathrm{Si}$ ratio of the samples studied met the required standard even before beneficiation while rheological properties such viscosity of the samples at $600 \mathrm{rpm}$ improved to a standard level after viscosifier was added to the samples. Unlike the results obtained by Falode et al. (2008) that Pindiga clays gives an ultimate results at maximum clay and additives concentration, our results shows that by using $\mathrm{Na}_{2} \mathrm{CO}_{3}$ as beneficiating agent, the uptimum yield is between 4 to $9 \% \quad \mathrm{Na}_{2} \mathrm{CO}_{3}$. It can be concluded that the API specified standards of $\geq 30$, $\leq 3, \leq 15, \leq 4$ and $\leq 13$ for viscosity at $600 \mathrm{rpm}$, yield, filtration, residual at $75 \mu \mathrm{m}$ and moisture content, respectively Schlumberger oil Field Glossary 2011 for Bentonite has been met after beneficiating the samples using sodium carbonate as beneficiating agent and ion exchange as procedure for beneficiation.

\section{AKNOWLEDGEMENT}

The researchers wish to acknowledge the following bodies for their efforts and immense contribution toward the success of this project:

- The Petroleum Technology Development Fund (PTDF), Abuja-Nigeria

- The Petroleum Training Institute (PTI), effurun, Warri, Delta State, Nigeria
- The Center for Energy Research and Training (CERT), Ahmadu Bello University, Zaria-Nigeria

- Department of Chemical Engineering, Ahmadu Bello University, Zaria-Nigeria

- The postgraduate students from Chemical Engineering and Geology Department that participated in field and laboratory works

\section{REFERENCES}

Abdessemed, D. and G. Nezzal, 2008. Bentonite used as adsorbent agent of the coupling adsorption ultrafiltration of the secondary effluents for their reuse. Am. J. Environ. Sci., 4: 716-720. DOI: 10.3844/ajessp.2008.716.720

Al-Kayiem, H.H., N.M. Zaki, M.Z. Asyraf and M.E. Elfeel, 2010. Simulation of the cuttings cleaning during the drilling operation. Am. J. Applied Sci., $\quad 7$ : 800-806. DOI: 10.3844/ajassp.2010.800.806

Benkhelil, J., 1985. Structure and Geodynamic evolution of the Intracontinental Benue trough (Nigeria). Paris: ELF Nigeria Ltd SNEA (P).

Falode, O.A., O.A. Ehinola and P.C. Nebeife, 2008. Evaluation of local Bentonitic clay as oil well drilling fluids in Nigeria. Applied Clay Sci., 39: 19-27. DOI: 10.1016/j.clay.2007.04.011

Guiraud, M., 1989. Explanation to geological map of parts of the Upper Benue valley. Elf Nigeria Limited.

Gungor, N., T. Tulun and A. Alemdar, 1998. Determination of trace elements by instrumental neutron activation analysis in Anatolian bentonitic clays. Nuclear Instrumentation Methods Phys. Res. B: Beam Interact. Mater. Atoms, 142: 555-560. DOI: 10.1016/S0168$583 \times(98) 00363-2$

NFS, 1956. Geological Map of Nigeria. 1st Edn., Federal Surveys, Lagos.

Zaborski, P., F. Ugodulunwa, A. Idornigie, P. Nnabo and K. Ibe, 1997. Stratigraphy and structure of the Cretaceous Gongola Basin, northeast Nigeria. Bull. Centres Recherches Exp.-Product. Elf Aquitaine, 21: 153-155.

Zaborski, P.M., 1998. The cretaceous system in Nigeria. Afr. Geol. Rev., 5: 385-484. 